\title{
Faktor-Faktor Yang Menghambat Perawat Dalam Pengisian Logbook Kompetensi Di Rumah Sakit
}

\author{
Komsiyah$^{1}$, Suhartono², Muhamad Rofi'i3 \\ ${ }^{1}$ Akademi Kesehatan Asih Husada Semarang \\ ${ }^{2}$ Fakultas Kesehatan Masyarakat, Universitas Diponegoro \\ ${ }^{3}$ Fakultas Kedokteran, Universitas Diponegoro, Semarang
}

\section{Informasi Artikel}

\section{Riwayat Artikel: \\ Diterima 29 Desember 2017}

\section{Kata Kunci:}

Log book; kompetensi

perawat; kredensial
Corresponding author:

Puput Risti Kusumaningrum puput.risti_ners@yahoo.co.id Jurnal Kepemimpinan dan Manajemen Keperawatan, Vol 1 No 1, Mei 2018 e-ISSN 2621-5047
Logbook oleh Komite Keperawatan merupakan salah satu cara yang digunakan dalam memastikan bahwa perawat telah kompeten melaksanakan kewenangan klinis yang diberikan kepadanya. Penggunaan logbook perawat terbukti bermanfaat sebagai alat monitoring dan evaluasi pelaksanaan kompetensi klinis dan alat pertanggungjawaban perawat terhadap penugasan klinis yang diberikan kepadanya. Tujuan studi ini untuk mengidentifikasi kelengkapan dokumen logbook kompetensi perawat di Rumah Sakit. Studi ini menggunakan metode penelitian gabungan (mixed methods) yakni metode yang memadukan pendekatan kuantitatif dan kualitatif dengan model sequential explanatory, dengan 136 resonden pada tahap pertama dengan mengobservasi 136 log book perawat, serta pada tahap kedua melakukan indepth interview yang melibatkan 9 partisipan utama serta 6 partisipan triangulasi untuk mengetahui faktor penghambat pelaksanaan pengisian logbook kompetensi perawat. Dari 136 log book perawat pelaksana diperoleh 13 (9,5\%) kelengkapan logbook baik, 41 (30,1\%) kelengkapan logbook cukup, dan $82(60,3 \%)$ kelengkapan logbook kurang. Hasil Indepth Interview memperoleh 8 tema, yakni fungsi logbook, kelengkapan dokumentasi logbook, waktu pelaksanaan pengisian, cara pengisian, faktor penghambat pengisian, faktor pendukung / pendorong pelaksanaan pengisian, serta dampak tidak melaksanakan pengisian logbook tepat waktu. Kesimpulan: Perlunya sosialisasi ulang kepada seluruh perawat guna meningkatkan pemahamn cara pengisian logbook yang benar, perlunya meningkatkan motivasi perawat melalui supervisi secara bertahap dan berkesinambungan serta perlunya menetapkan reward yang jelas terkait dengan pelaksanaan pengisian logbook perawat. 


\section{PENDAHULUAN}

Bukti dari pelaksanaan tindakan perawat sesuai dengan kompetensi kewenangan klinisnya dicatat dalam logbook. Logbook tersebut oleh Komite Keperawatan merupakan salah satu cara yang digunakan dalam memastikan bahwa perawat telah kompeten melaksanakan kewenangan klinis yang diberikan kepadanya. Penggunaan log book perawat terbukti bermanfaat sebagai alat monitoring dan evaluasi pelaksanaan kompetensi klinis dan alat pertanggungjawaban perawat terhadap penugasan klinis yang diberikan kepadanya (PMK no. 49, 2013; Kemenkes, 2013). Kompetensi perawat yang kurang sesuai dengan permasalahan kesehatan pasien akan membuat penaganan pasien terhambat dan adanya ancaman keselamatan pasien. Kejadian yang menyebabkan ancaman keselamatan pasien yang ada sekarang banyak terjadi karena adanya kesalahan, kelalaian dan kurang tanggap terhadap situasi yang terjadi di Rumah Sakit (Carryer, Gardner, Dunn, \& Gardner, 2007; Neuner-Jehle S, Schmid M, 2013; Wachter, 2015).

Studi pendahuluan yang dilakukan pada bulan Januari 2016 di Rumah Sakit pemerintah di Semarang dengan studi dokumentasi, lembar observasi dan wawancara. Hasil observasi dokumen logbook perawat menggunakan lembar observasi dari 20 logbook perawat yang diambil secara acak menunjukkan logbook 65 \% kelengkapan kurang, 30\% kelengkapan sedang, serta hanya 5\% kelengkapan baik. Hasil wawancara bahwa perawat dalam melakukan pengisian log book belum optimal, pengisiannya tidak tentu dilakukan setiap hari, pada bulan Januari 2016 jumlah perawat yang dilakukan kredensial sekitar 456 perawat $(32,88 \%)$, jadi sekitar $67,12 \%$ perawat belum mengikuti proses kredensial.
Penyampaian dari 10 perawat dari ruang yang berbeda bahwa dalam melakukan pengisian log book jarang dilakukan setiap hari, yang penting pada saat melakukan kredensial log book terisi. Berbeda dengan penelitian yang dilakukan oleh Fatemeh, et al, bahwa log book bisa dimanfaatkan dengan baik jika pengisiannya dan pengumpulannya dilakukan tepat setiap hari sehingga akan dihasilkan data yang valid, relevan dan dapat diandalkan (Fatemeh \& Alavinia, 2012).

Kelengkapan dokumentasi logbook kompetensi perawat merupakan bukti bahwa tanggung jawab hukum dan etik perawat terhadap pasien terpenuhi dan pasien telah menerima asuhan keperawatan yang bermutu. Dengan logbook yang lengkap pula bahwa perawat akan terhindar tuntutan/ komplain dari pasien apabila ditemukan adanya kejadian yang tidak diharapkan (adverse events).

Mengidentifikasi kelengkapan dokumen log book kompetensi perawat di Ruang Rawat inap Rumah Sakit

\section{METODE}

Metode penelitian yang digunakan pada penelitian ini adalah metode penelitian gabungan (mixed methods) yakni metode yang memadukan pendekatan kuantitatif dan kualitatif (sequential explanatory), yakni pengumpulan data dan analisis data kuantitatif pada tahap pertama kemudian diikuti dengan pengumpuan dan analisis data kualitatif pada tahap ke dua guna memperkuat hasil penelitian kuantitatif yang dilakukan pada tahap pertama.

Penghitungan jumlah sampel dengan menggunakan tabel hitung dari Sugiyono dengan taraf kesalahan 10\%, maka jumlah sampelnya 133 dari populasi 260 . Karena populasi berstrata maka samplenya juga berstrata. Strata ditentukan menurut jenjang karir harus 
proporsional sesuai dengan populasi mulai Pra perawat klinik (PK), PK I, PK II, PK III. Jumlah sampel 136 orang yang terdiri dari Pra PK 44 orang, PK I 66 orang, PK II 3 orang, dan PK III 23 orang.

Tahap ke dua pada penelitian ini jenis penelitian yang telah digunakan adalah dengan desain penelitian kualitatif. Pendekatan kualitatif ini merupakan lanjutan dari tahap pertama, pada tahap ke dua ini telah dilakukan pengumpulan data untuk mencari faktor-faktor yang menjadi penghambat perawat dalam mengisi log book sesuai dengan penugasan klinisnya, faktor pendukung dari manajemen serta upaya yang dilakukan pihak manajemen dalam mengatasi hambatan pengisian log book kompetensi perawat di rumah sakit Semarang.

Tabel 1. Tema faktor penghambat pengisian logbook kompetensi

\begin{tabular}{|c|c|c|c|}
\hline No & Kata Kunci & Kategori & Tema \\
\hline 1. & Tidak tau cara mengisi yang benar (P1,P4) & Pengetahuan & Faktor penghambat \\
\hline \multirow[t]{2}{*}{2.} & Belum ada sosialisasi (P1) & Belum ada & pengisian logbook \\
\hline & Sosoalisasinya belum ada (P9) & sosialisasi & kompetensi \\
\hline \multirow[t]{6}{*}{3.} & Tidak ada kesempatan untuk menulis (P1) & Sibuk & \\
\hline & Terlalu sibuk, ndak ada waktunya (P2) & & \\
\hline & Repot sekali (P3) & & \\
\hline & Banyak Program (P4) & & \\
\hline & Pasien tidak sedikit dan pelayanan cepat (P6) & & \\
\hline & Sedang sibuk (P7) & & \\
\hline \multirow[t]{2}{*}{4.} & Tidak punya tenaga untuk menulis (P1) & Kecapean & \\
\hline & Sudah capek (P4, P7,P8) & & \\
\hline \multirow[t]{3}{*}{5.} & Dorongan diri belum ada (P1) & Kurang semangat & \\
\hline & Manfaat belum ada (P1) & & \\
\hline & Males (P4, P7) & & \\
\hline \multirow[t]{4}{*}{6.} & Hanya mengingatkan (P2) & Pimpinan hanya & \\
\hline & Sebatas mengingatkan (P3) & memberikan & \\
\hline & Ngopayak-ngopyak untuk nulis (P3) & pengarahan & \\
\hline & Diingatkan (P4, P7, P9) & & \\
\hline \multirow[t]{5}{*}{7.} & Menulis manual repot $(\mathrm{P} 1, \mathrm{P} 9)$ & Logbook tidak & \\
\hline & Model bukunya manual butuh waktu lama (P3) & mudah cara & \\
\hline & Bingung, susah ngisinya(P6) & mengisinya & \\
\hline & Diganti yang baru yang mudah (P7) & & \\
\hline & Yang lebih simpel tidak ribet (P8) & & \\
\hline \multirow[t]{3}{*}{8.} & Belum ada reward khusu untuk logbook (P1) & Belum ada reward & \\
\hline & Reward belum masuk logbooknya (P6) & khusus logbook & \\
\hline & $\begin{array}{l}\text { Reward berhubungan logbook dengan logbook ndak } \\
\text { ada }\end{array}$ & & \\
\hline
\end{tabular}




\section{HASIL}

Hasil penelitian pada tahap pertama tentang distribusi kelengkapan dokumentasi logbook perawat menunjukkan bahwa logbook yang isiannya kurang lengkap adalah paling banyak yakni mencapai 82 (60,3\%), kelengkapan cukup sebanyak 41 (30,1\%), sedangkan logbook yang lengkap hanya $13(9,5 \%)$ dari total 136 logbook perawat.

Tahap kedua Peneliti telah mengidentifikasi 8 tema dalam penelitian ini, yakni fungsi logbook kompetensi, kelengkapan dokumentasi logbook, waktu pelaksanaan pengisian logbook, cara mengisi logbook, faktor penghambat pengisian logbook, faktor pendukung / pendorong pelaksanaan pengisian logbook, upaya manajemen dalam mengatasi hambatan pelaksanaan pengisian logbook kompetensi, serta dampak tidak melaksanakan pengisian logbook tepat waktu.

Faktor penghambat pengisian logbook teridentifikasi sebagai tema dalam penelitian ini, diantaranya karena pengetahuan perawat, belum ada sosialisasi, karena perawat sibuk, perawat kecapean, kurangnyanya semangat perawat, pimpinan hanya memberikan pengarahan, logbook tidak mudah dalam pengisiannya, serta belum ada reward khusus logbook.

\section{DISKUSI}

Faktor yang menghambat pengisian logbook teridentifikasi sebagai tema dalam penelitian ini yang terjawab dari hasil wawancara dengan partisipan, antara lain karena pengetahuan perawat, belum ada sosialisasi, sibuk, kecapean, kurang semangat, pimpinan hanya memberikan pengarahan, logbook tidak mudah dalam pengisiannya, serta belum ada rewad khusus terkait dengan logbook

Pengetahuan adalah kumpulan informasi yang difahami, diperoleh dari proses belajar selama hidup dan dapat digunakan sewaktu-waktu sebagai alat penyesuaian diri baik terhadap diri sendiri maupun lingkungannya (Hani, 2006).
Sejalan dengan hasil penelitian yang menunjukkan bahwa ada hubungan antara pengetahuan perawat dengan kelengkapan dokumentasi dengan hasil P:0,001 $(\mathrm{P}<0,05)$, ini menunjukkan pentingnya pengetahuan harus selalu ditingkat.

Ada 2 dari 9 partisipan yang menyampaikan bahwa belum ada sosialisasi cara penulisan yang benar tentang logbook ini. Meskipun hanya 2 partisipan yang menyampaikan, namun hal itu menunjukkan bahwa sosialisasi belum merata dilakukan. Sosialisasi merupakan salah satu kebijakan strategi yang dilakukan untuk meningkatkan pemahaman dan kejelasan. Sosialisasi harus dilaksanakan secara berkala untuk meningkatkan pemahaman perawat pelaksana terkait dengan cara pengisian logbook yang benar sehingga penerapannya dapat berjalan dengan baik dan dihasilkan dokumentasi logbook yang lengkap. Sejalan dengan hasil penelitian Sari et al, bahwa terdapat perbedaan yang signifikan antara sebelum dan sesudah dilakukan sosialisasi (Sari \& Solechan, 2014).

Kesibukan perawat juga merupakan faktor penghambat pengisian logbook. Hal ini juga diungkapkan oleh partisipan triangulasi berikut ini:

“ ...paling banyak itu...karena aktivitasnya ya..terkendala waktunya, waktu untuk pengisian" (T1)

" ...saat itumemang krodit..beban kerjanya memang tinggi...tidak ada waktu untuk menulis" (T3)

“..mungkin karena kerjaannya terlalu banyak, sibuk sehingga seringnya itu dirapel" (T4)

" Mungkin karena beban kerja yang tinggi itu bisa saja terjadi” (T6)

Manajemen waktu yang baik ini sangat penting dilakukan perawat, dalam hal ini adalah mengelola waktu dengan baik dalam mengisi kelengkapan logbook. Manajemen waktu merupakan kemampuan mengalokasikan waktu dan sumber daya untuk mencapai tujuan. Menciptakan keseimbangan antara pekerjaan dan kehidupan pribadi. Manajemen waktu 
bukan hanya mengacu kepada pengelolaan waktu, tetapi lebih cenderung pada bagaimana memanfaatkan waktu. Individu yang mampu mengelola waktu akan menentukan prioritas dari berbagai tugas yang dihadapi dan akan mendapatkan kepuasan serta dapat mengurangi kegalauan dan kecemasan (Claessens, 2007).

Faktor kecapean juga terungkap oleh 4 partisipan pada saat wawancara. Kecapean atau kelelahan adalah suatu mekanisme perlidungan tubuh agar tubuh terhindar dari kerusakan yang lebih lanjut sehingga terjadi pemulihan setelah istirahat. Klelahan diatur secara sentral oleh otak, pada susuanan saraf terdapat sistem aktivitas (bersifat simpatis) dan inhibisi (bersifat parasimpatis). Kelelahan menujukkan kondisi yang berbeda-beda pada setiap individu, tetapi semuanya bermuara pada kehilangan efesiensi dan penuruan kapasitas kerja serta ketahanan tubuh (Tarwaka, 2011).

Kecapean atau kelelahan akan berimbas pada produksi kerja, salah satunya adalah hasil dokumentasi pada logbook, karena merasa kecapean sehingga perawat enggan untuk menulis kegiatan yang telah dilakukannya pada logbook sehingga dokumentasi data pada logbook kurang lengkap atau tidak bahkan tidak lengkap. Hal ini sesuai dengan hasil penelitian yang dilakukan oleh Muizzudin, menunjukkan bahwa ada hubungan anatara kelelahan kerja dengan produktivitas kerja dengan nilai ( $\mathrm{P}=0,001)$ (Muizzudin, 2013).

Kelelahan kerja juga merupakan kriteria yang kompleks yang tidak hanya menyangkut pada kelelahan fisiologis dan psikologis, tetapi dominan hubungannya dengan penurunan kinerja fisik dan juga adanya perasaan lelah, serta penuruanan motivasi, selain itu juga terjadi penuruan produktivitas kerja (Silastuti, 2006).

Semangat kerja ini merupakan kemamuan atau kesediaan dari setiap individu atau kelompok untuk salin bekerjasama dengan giat, disiplin dan penuh rasa tanggung jawab dalam melaksanakan tujuan yang telah ditetapkan oleh perusahaan, akan tetapi dalam hal ini tiap individu dipengaruhi oleh keinginan atau motif tertentu sesuai dengan kebutuhannya. Jika keinginan atau motif tersebut tidak terpenuhi maka dapat menurunkan semangat kerja karywan, dan sebaliknya jika kebutuhan terpenuhi maka dapat meningkatkan semangat kerja karyawan. Semangat kerja bisa dihubungkan dengan penilaian kinerja, jika dikaitkan dengan pernyataan yang disampaikan oleh partisipan bahwa:

"....sudah bekerja 16 tahun ya...untuk naik PK IV juga belum, denger-denger juga fee juga ndak jauh beda dengan PK III jadi kalau saya ndak ngoyo naik..." (P1)

Pernyataan tersebut mengisyaratkan bahwa manakala perawat sudah melakukan pengisian logbook dengan lengkap namun kenyataannya tidak diimbangi dengan penghasilan yang memadai maka akan menimbulkan turunnya semangat. Apalagi dalam kenyataannya dokumen logbook ini harusnya dapat berfungsi sebagai salah satu sumber data penilaian kinerja di rumah sakit tersebut, namun kenyataan dilapangan belum bisa terlaksana, seperti pernyataaan partisipan teriangulasi bahwa:

"Tidak...penilaian kinerja kita berorientasi kepada kebutuhan manajemen ya, kalau itu kan apa..kalau kita lihat...jadi manajemen itu membantu memfasilitasi" (T5)

Faktor penghambat pengisian logbook lainnya dikarenakan pimpinan hanya memberikan pengarahan saja. Kepala ruang hanya sebatas mengingatkan saja pada perawat dan untuk pengecekan isian logbook. Pengecekan yang dimaksudkan adalah supervisi dari kepala ruang terhadap pelaksanaan pengisian logbook menurut persepsi perawat. Dalam penelitian yang dilakukan oleh Astuty juga menujukkan hasil bahwa supervisi kepala ruang yang dianggap baik oleh perawat akan berpeluang 2,766 kali lebih besar untuk merasa puas dengan pekerjaannya dibanding perawat pelaksana yang mempersepsikan kurang baik (Astuty, 
2011). Sejalan dengan hasil penellitian yang dilakukan oleh Nindyanto, bahwa supervisi kepala ruang yang baik akan meningkatkan peluang pendokumentasian asuhan keperawatan 3 kali lebih baik $(\mathrm{OR}=3,222)$, sehingga semakin baik supervisi kepala ruang semakin baik pula kelengkapan pendokumentasian (Nindyanto, 2013).

Supervisi merupakan proses atau upaya meningkatkan kinerja atau ketrampilan seseorang pada pekerjaan tertentu seperti halnya supervisi terhadap pelaksanaanya pengisian logbook atau supervisi terhadap dokumenasi logbook itu sendiri. Hawkins \& Shohet mengatakan bahwa supervisi merupakan hubungan seseorang yang intensif dengan orang lain, fokus secara interpersonal dimana orang tersebut berupaya untuk memfasilitasi perkembangan kompetensi pada orang lain (Hawkins \& Shohet, 2006). Namun pada saat diklarifikasi pada partisipan triangulasi mereka menyampaikan bahwa supervisi yang dimaksudkan untuk mengecek pelaksanaan dan dokumentasi logbook tidak hanya dilakukan oleh kepala ruang, karena di rumah sakit tersebut supervisi ini dilakukan secara berjenjang, yakni untuk perawat asosiet akan disupervisi oleh Perawat penanggung jawab pasien (PPJP), dan PPJP akan disupervisi oleh kepala ruang. Seperti yang teruangkap pada saat wawancara mendalam berikut:

“...jadi kalau logbook itu kan sebetulnya bentuk supervisi berjenjang PA nanti akan diawasi oleh PPJP dan selanjutnya PPJP akan diawasi oleh disupervisi oleh kepala ruang, dengan adanya supervisi itu ya harapannya temen-temen patuh untuk mengisi logbook itu sendiri" (T1) "....setelah menulis seperti itu akan diklarifikasi ditandatangani oleh level diatasnya, kalau pra PK yang menandatangani PK I,PK I yang menandatangani PK II, PK II yang menandatangani PK III, PK III yang menadatangani kepala ruangnya" (T3).

Partisipan triangulasi juga menyampaikan bahwa selama ini karena memang logbook ini merupakan dokumen pribadi dari masing-masing perawat, jadi pelaksanaanya menjadi tanggungjawab secara pribadi perawat yang bersangkutan, kepala ruang hanya sebatas mengingatkan saja tidak bisa menegur satu persatu perawat yang tidak mengisi logbook setiap hari, karena itu sudah menjadi tanggung jawab pribadi perawat. Seperti ungkapan partisipan triangulasi berikut:

"Ya mengingatkan, karena gini di...sistemnya..artinya gini..itu kan urusan pribadi, atasan hanya sebatas mengingatkan, apakah harus sampai ini itu ditegur..diingtakan..kan ndak juga itu kan pribadi, kita sudah diingatkan tapi dia nggak buat ketika dibutuhkan kan dia bingung sendiri kan, hanya sebatas mengingatkan, kalau tidak dihiraukan ya..terserah itu urusan pribadi" (T2)

Pernyataan partisipan triangulasi tersebut menunjukkan bahwa sebagai kepala ruang dalam pelaksanaan pengisian logbook sudah mengingatkan, mengingatkan sama halnya dengan memberikan motivasi pada perawat, motivasi tersebut merupakan bagian dari fungsi pengarahan kepala ruang. Kepala ruang berpersepsi bahwa logbook ini merupakan tanggung jawab pribadi dari masing-masing perawat, sehingga jika sudah diarahkan, diingatkan, kemudian mereka tidak melakukan maka resikonya akan ditanggung sendiri oleh masingmasing perawat, seperti penangguhan kenaikan pangkat.

Logbook menurut ungkapan partisipan tidak mudah dalam mengisinya, ribet, dan memutuhkan waktu lama. Juga merupakan faktor penghambat pengisian. Namun seharusnya penulisan logbook manual yang merepotkan dari partisipan tersebut bukan menjadi hambatan perawat dalam mengissinya, karena di rumah sakit ini sudah menyediakan petunjuk cara pengisannya, meskipun pengisiannya manua, namun ini dapat digunakan perawat dalam membutktikan kompetensi yang perawat melaksanakan sesuai dengan levelnya. 
Logbook manual tersebut dipersepsikan perawat masih sulit pelaksanaan penulisannya, butuh waktu yang lama dalam mengisi sehingga tidak bisa langsung mengisi setiap harinya. Menurut Cern \& Athena juga menyampaikan bahwa kekurangan dari logbook yang ditulis tangan adalah membutuhkan waktu yang banyak dan apabila proses penulisanya yang tergesa-gesa akan sulit untuk dipahami di waktu yang akan datang, bahkan oleh penulisnya sendiri (Cern \& Athena, 2006).

Model logbook manual yang membutuhkan waktu lama dalam mengisi dan melengkapinya dirasa mereptokan perawat dilihat dari persepsi perawat, seperti hasil penelitian yang dilakukan oleh Diyanto, bahwa salah satu hambatan perawat dalam melengkapai pendokumentasian adalah karena format yang terlalu panjang yang menyulitkan perawat dalam menuliskannya, sehingga dibutuhkan waktu yang lama dalam melengkapinya (Diyanto, 2007).

Hasil penelitian ini mengungkapkan juga tentang penghambat dalam mengisi logbook adalah karena belum ada reward khusus tentang logbook. mereka menganggap bahwa reward secara nyata terkait dengan logbook ini belum ada. Memberikan reward (penghargaan) dapat dipandang sebagai upaya peningkatan motivasi kerja, imbalan yang diberikan akan memotivasi individu untuk bekerja dengan baik, perawat yang mendapatkan imbalan sesuai dengan peran dan tugas pokok yang mereka lakukan akan termotivasi untuk melakukan suatu pekerjaan yang lebih baik seperti pelaksanaan pengisian logbook dan melengkapinya ( Notoatmodjo, 2009).

Salah satu tujuan pemberian kompensasi juga dapat meningkatkan produktivitas yang berdampak pada peningkatan kinerja perawat, seperti kinerja perawat dalam melengkapai isian logbook meskipun itu sifatnya individu yang nantinya akan bisa digunakan dalam peningkatan jenjang karir perawat. Hasil penelitian yang dilakukan oleh Andri et al, juga menunjukkan ada pengaruh yang bermakna antara imbalan terhadap kelengkapan dokumentasi keperawatan, begitu juga bila diterapkan pada hasil dokukementasi logbook perawat (Andri, Indra, \& Susmarini, 2015).

\section{KESIMPULAN}

Kelengkapan dokumentasi logbook perawat di Rumah Sakit dari 136 logbook yang telah diobservasi terdapat $60,3(82 \%)$ kelengkapan kurang, $41 \quad(30,1 \%)$ kelengkapan cukup, dan 13 (9,5\%) kelengkapan baik.

Kelengkapan dokumentasi logbook dari ungkapan partisipan belum menyampaikan adanya dokumentasi identitas pemilik logbook, namun hanya memuat keterangan hari, tanggal, jam; dokumentasi identitas pasien; dokumentasi kegiatan pelayanan atau asuhan keperawatan; dokumentasi keterangan dinas; dokumentasi kegiatan bimbingan; dokumentasi kegiatan pendidikan dan pelatihan; serta dokumentasi tanda tangan dari kepala ruang atau PPJP.

Faktor yang menjadi penghambat perawat dalam melaksanakan pengisian logbook antara lain dari pengetahuan perawat itu sendiri, kesibukan, kecapean, kurangnya semangat diri, pimpinan yang hanya memebrikan pengarahan, logbook tidak mudah dalam mengisinya, serta belum adanya reward khusus logbook.

\section{DAFTAR PUSTAKA}

Andri, F., Indra, R., \& Susmarini, D. (2015). Analisis faktor-faktor yang mempengaruhi perawat dalam memenuhi kelengkapan dokumentasi keperawatan di igd rumah sakit wilayah pontianak kalimantan barat. Jurnal Medika Respati, 10(4).

Astuty, M. (2011). Hubungan pelaksanaan fungsi pengarahan kepala ruang dengan kepuasan kerja perawat pelaksana. Tesis Program Pascasarjan Universitas Indonesia.

Carryer, J., Gardner, G., Dunn, S., \& Gardner, A. (2007). The core role of the nurse practitioner: practice, professionalism and clinical http://doi.org/10.1111/j.13652702.2006.01823.x 
Cern, \& Athena. (2006). Tests the digital logbook.

Claessens, et al. (2007). A review of the time management literature. Personnel Review, 36(2), 255-275.

Diyanto, Y. (2007). Analisis faktor-faktor Pelaksanaan Dokumentasi Asuhan Keperawatan Di Rumah Sakit Umum Daerah Tugurejo Semarang. Tesis Program PAscasarjana UNdip.

Fatemeh, K., \& Alavinia, S. M. (2012). Students' perception about logbooks: Advantages, limitation and recommendation - A qualitative study. Journal of the Pakistan Medical Association, 62(11), 1184-1186.

Hawkins P, Shohet R. (2006). Supervission in the helping professions. London: YHT, Ltd.

Hani. (2006). Manajemen Personalia dan Sumberdaya Manusia. Yogyakarta: BpFE.

Muizzudin, A. (2013). Hubungan antara kelelahan kerja dengan produktivitas kerja pada tenaga kerja bagian tenun di pt. Alkatex tegaL. Penelitian Tidak Dipublikasikan Jurusan Ilmu Kesehatan Masyarakat Fakultas Ilmu Keolahragaan Universitas Negeri Semarang.

Nindyanto, S. I. A. (2013). Pengaruh supervisi kepala ruang terhadap pendokumentasian asuhan keperawatan. Peneleitian Tidak Dipublikasikan.

Neuner-Jehle S, Schmid M GU. Neuner-Jehle S, Schmid M, Grüninger U. (2013). The "Health Coaching" programme: a new patient-centred and visually supported approach for health behaviour change in primary care. BMC Fam Pract [Internet]. 2013 Jan;14:100. Available from: http://www.pubmedcentral.

Notoatmodjo, S. (2009). Pengembangan Sumber Daya Manusia. Jakarta: Rineka Cipta.

PMK no 49 Tahun 2013 Tentang Komite Keperawatan.

Roshadi, I. (2014). Hubungan kelelahan kerja dengan produktivitas kerja. Penelitian Tidak Dipubikasikan.

Sari, R. Y., Suprapti, E., \& Solechan, A. (20014). Pengaruh sosialisasi sop apd dengan perilaku perawat dalam penggunaan apd (handscoon, masker, gown) di rsud dr. H. Soewondo. Jurnal Keperawatan Dan Kebidanan (JIKK).

Silastuti, A. (2006). Hubungan Antara Kelelahan dengan Produktivitas Tenaga Kerja di bagian Penjahitan PT Bengawan Solo Garment Indonesia. Penelit Univ Negeri Semarang

Tarwaka. (2011). Ergonomi Industri Dasar-Dasar Pengetahuan dan Aplikasi di Tempat Kerja.. Surakarta: Harapan Press. 